\title{
Production Analysis of Inland Fish in Angul District of Odisha
}

\author{
${ }^{1}$ Mitali Krishna Kumari, ${ }^{2}$ Dr Sudhakar Patra \\ ${ }^{I}$ Research Scholar, Ravenshaw University, Cuttack \\ ${ }^{2}$ Head, dept of Economics, Ravenshaw university, Cuttack
}

\begin{abstract}
The objective of this paper is to analyse the production of inland fish in Angul district of Odisha. The study is based on primary data collected from 250 fisher men from two blocks of the district. The Production of inland fisherman is positively related to its land, days of fishing, hours of fishing, cost of net used \& water area of production. The days of fishing varying from 50 days to 300 days in a year. 38 numbers of fisherman households are working 100-150 days \& 26 fishermen are working with the period ranging from 50-100 days. Only 7 numbers of inland fishermen are giving maximum days towards fish cultivation, those who are not doing any other work for their livelihood. Income of inland fisherman is positively related to its land, days of fishing, hours of fishing, cost of net used \& water area of production.
\end{abstract}

Key Words: Cost, Income, Net Inland Fish, Production, Water Area

\section{Introduction}

Fishery has been one of the most ancient but important source of livelihood for a large population. Fishing has been a traditional occupation for millennia, supporting a plethora of communities, both along the sea coast and inland. The sector contributes significantly to employment and is a big foreign exchange earner. After agriculture and weaving, fishing is the largest sector in terms of livelihood generation. However, traditional fishermen are under pressure from large scale unregulated industrialization, export-oriented, mechanized fishing and aquaculture. Fisheries Sector has been recognized as one of the powerful income and employment generators as it stimulates growth of a number of subsidiary industries. Fish being a source of cheap animal protein, is an important source of diet for a large section of economically backward population of the country. Fisheries are the only sector that offers cheap and good animal protein to the people, particularly to the economically weaker sections of the society. Thereby, it serves as a means for ensuring national food security. It is also a major contributor towards foreign exchange earnings for the country through export of fish and fish products. The potential of forward and backward linkages through boat building, construction of fishing harbors', fish processing etc., contribute further to diversification and strengthening of regional and national economy.

Fishing trade is held as one of the very useful allied activities associated with the primary sector of an Indian economy. Sincere effort should be unleashed to exploit the best possible advantages and opportunities laying unexplored in this sector. The country of course today has occupied the $8^{\text {th }}$ position in fish production among the fishing nations of the world and the number one position with regard to export of prawns. India as a maritime country has a vast potential of fishing resources comprising 2 million Sq. Kms of exclusive economic zone for deep fishing 7,520 Kms coast line, 29,000 Kms of rivers, 1.7 million hectares of reservoirs, nearly 1 million hectares of brackish water area and 0.8 million hectares of tanks and ponds for inland and marine fish production. Indian fisheries and aquaculture are important sectors of food production, providing nutritional security to the food basket, contributing to the agricultural exports and engaging about fourteen million people in different activities. With diverse resources ranging from deep seas to lakes in the mountains and more than $10 \%$ of the global biodiversity in terms of fish and shellfish species, the country has shown continuous and sustained increments in fish production since independence. Constituting about $4.4 \%$ of the global fish production, the sector contributes to $1.07 \%$ of the GDP and $4.7 \%$ of the agricultural GDP. The total fish production of 6.4 million metric tonnes presently has nearly 55\% contribution from the inland sector and nearly the same from culture fisheries. Paradigm shifts in terms of increasing contributions from inland sector and further from aquaculture are significant over the years. With high growth rates, the different facets of marine fisheries, coastal aquaculture, mariculture inland fisheries, freshwater aquaculture and coldwater fisheries are increasingly being diversified, contributing to food, health, economy, exports, employment and tourism of the country.

\section{Literature Review}

Anjani Kumar (2004) studied in detail the export performance of Indian fisheries. Fisheries exports have registered a tremendous growth during the period 1987-2000 and the export basket of fisheries products has become reasonably diversified. In this study he found that, export of frozen fish record the highest animal 
growth, but shrimps and prawns constituted the major category of export, capturing and impressive 5\% of the world export market. Kapotsky and Peter (1998) described the dynamic nature of inland water bodies and the diversity of their aquatic fauna. Fisheries prosperity will not occur unless management of the aquatic environment is improved and its benefit better shared. Even within the sector more integrated approaches were being suggested in fisheries eco-system management, which is a reasonable proxy for other integrated area management scheme in coastal, inland river basin bioregions.

Collier, W ebb and Shlmidt (1996) gave an accounts of the dams and rivers of the world and the construction of large dams in United states in detail. These changes are also reflected in the composition of the inland fish fauna. The greatest threat to the sustainability of inland fisheries resources is not over exploitation. Neiland \& Bene (2006) attempted to address the lack of valuation for inland fisheries, some studies confirm the substantial values of inland fisheries. For the sector is remarkably low compared with other food production systems. Fisheries use energy in three main ways: the manufacturer of gear; move to and from fishery site; and preservation and post-harvest transport.

Sainbury. K,(2010) summarized the standards, requirements, and practices for well managed fisheries as applied through internationally managed fisheries and through national management of fisheries. The standards, requirements and practices of existing fishery ecolabels are reviewed, including government- linked ecolabels, non-government ecolabels seafood. He also found that, Inland fishery often involve significant artificial enhancements and practices that are characteristics of aquaculture, such as species introduction and translocations, artificial breeding or freeding, disease control animal husbandry, nutrient fertilization intentional habitat modification.

Arun V. Holden, (1981) stated that, inland fisheries have become increasingly recognize in many regions as a source for food for local population, a social recreational resource and a means of attracting foreign currency, whether by export sale of fish or through of encouragement of tourism through angling. Supra Raju (2003) emphasized the need for the development of fisheries sector in Andhra Pradesh by improving the availability of infrastructure facility per landing.

\section{Production Analysis of Inland Fishery in Anugul}

Production of fish depends upon various factors. Through production analysis, an attempt has been made here to set up a relationship between production of fish and different factors like land, age, hours of fishing, days of fishing, and cost of net, water area. etc. The study is based upon primary data. Following is the general form of production function (Linear type of production function) which is employed to estimate production elasticities.

$$
\mathrm{Q}=\mathrm{f}(\mathrm{L}, \mathrm{A}, \mathrm{D}, \mathrm{C}, \mathrm{H}, \mathrm{W})
$$

Here,$Q=$ Total Production, $\mathrm{L}=$ land, $\mathrm{A}=$ Age of entry into fishing, $\mathrm{D}=$ Days of fishing, $\mathrm{C}=$ Cost of net, $\mathrm{H}=$ Hours of fishing, $\mathrm{W}=\mathrm{W}$ ater area

Data pertaining to output, land area, age, cost on net, hours of fishing, days of fishing, sources of finance \& water area etc. were elicited from 250 fish farmers selected for the study from Angul district by administering the questionnaire designed for the purpose.

Table-1 Regression Results Inland fish production function in Angul Block

\begin{tabular}{|l|l|l|l|l|}
\hline Production & Coefficient & Standard Error & $\mathrm{t}$ & $\mathrm{P}>|\mathrm{t}|$ \\
\hline Land & 11.33848 & 32.60089 & 0.35 & 0.792 \\
\hline Days of fishing & .8346521 & .6718495 & 1.24 & 0.217 \\
\hline Cost of net & -.0028521 & .0094246 & -0.30 & 0.763 \\
\hline Hours of fishing & 38.88958 & 23.1946 & 1.68 & 0.096 \\
\hline Water area & 432.0505 & 47.63945 & 9.07 & 0.000 \\
\hline Constant & 93.8887 & 120.7296 & 0.78 & 0.438 \\
\hline
\end{tabular}

Source- Author's calculation using SPSS

$\mathrm{Q}=93.8887+11.33848 \mathrm{~L}+.8346521 \mathrm{D}-.0028521 \mathrm{C}+38.88958 \mathrm{H}+432.0505 \mathrm{~W}$

$\left(\mathrm{t}=0.78, \mathrm{R}^{2}=0.7535\right)$

Here, $\mathrm{L}=\mathrm{Land}, \mathrm{D}=$ Days of fishing, $\mathrm{C}=$ Cost of net used, $\mathrm{H}=$ Hours of fishing, $\mathrm{W}=$ Water area

The null hypothesis is that there is no relationship, i.e., the regression coefficient is not different from zero. The p-value for beta coefficient of land is 0.792 , the same for days of fishing is 0.217 , for cost of net is 0.763 , for hours of fishing is 0.096 and for water area is 0.000 . Both these values are significant at $10 \%$ significance level. Thus we cannot accept the null hypothesis. In other words, we can conclude that the Production of inland fisherman is positively related to its land, days of fishing, hours of fishing, cost of net used $\&$ water area of production. So the regression co-efficient is significant. 


\section{Income Analysis of Inland Fishing}

Income is the key factor which motivates fisher men for fishing. Many fishermen in study area have substantial income from fishing compared to other occupations. The monthly income from fishing is given below in table-2.

Table-2 Monthly income from fishing

\begin{tabular}{|l|l|}
\hline Income from fishing & No. of fisherman \\
\hline $5000-10000$ & 43 \\
\hline $10000-15000$ & 60 \\
\hline $15000-20000$ & 19 \\
\hline $20000-25000$ & 3 \\
\hline
\end{tabular}

Source- Field Study

The above data in table represent that, the monthly income of inland fisher man from fishing is varying from Rs. 5000 to Rs.25000. Here, 43 numbers of fisherman household are earning Rs. 5000 to Rs 10000 per month and 60 numbers of household earned Rs.10000 to Rs.20000 but only 7 household earned Rs.2000025000 from fishing.

Figure-1 Monthly income from fishing by inland fisherman

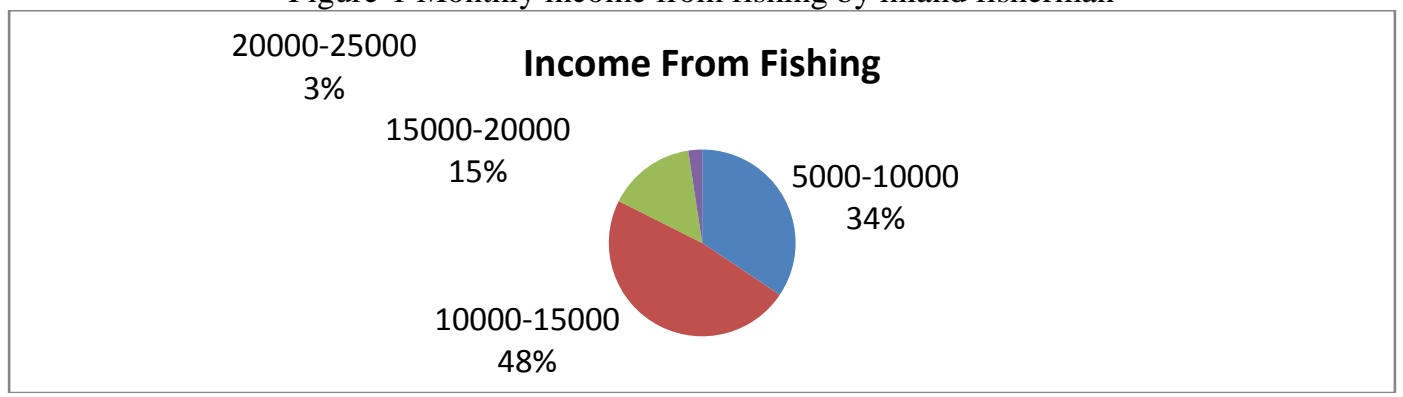

From the above pie-chart, it is cleared that only $3 \%$ of inland fisherman from the total sample is earning Rs.20000-25000 where as 48\% fisherman are earning Rs.10000 - 15000. Income is a function of land, age of entry into fishing, hours of fishing, and days of fishing, cost of net \& water area. Here, income is dependent variable (DI) \& all others are independent variable (IV).

So, Income $=\mathrm{f}($ Land, Age, Hours of fishing, Days of fishing, Cost of net, Water area $)$

Table-3 Regression Results of Income function of inland fisherman

\begin{tabular}{|l|l|l|l|l|}
\hline Income From Fishing & Coefficient & Standard Error & $\mathrm{t}$ & $\mathrm{P}>|\mathrm{t}|$ \\
\hline Land & 51.24936 & 247.3199 & 0.21 & 0.836 \\
\hline Days of fishing & 14.87539 & 5.096847 & 2.92 & 0.004 \\
\hline Cost of net & .3101072 & .0714981 & 4.34 & 0.000 \\
\hline Hours of fishing & 256.7641 & 175.9611 & 1.46 & 0.147 \\
\hline Water area & 907.5546 & 361.4068 & 2.51 & 0.013 \\
\hline Constant & 3261.13 & 915.8904 & 3.56 & 0.001 \\
\hline
\end{tabular}

Source- Author's calculation using SPSS

Income $=3161.13+51.24936 \mathrm{~L}+14.87539 \mathrm{D}+.3101072 \mathrm{C}+256.7641 \mathrm{H}+907.5546 \mathrm{~W}$

$\mathrm{t}=0.56, \mathrm{R}^{2}=0.5568$

The p-value for coefficient of Land is 0.836 , the same for days of fishing is 0.004 , for cost of net is 0.000 ,for hours of fishing is 0.147 and for water area is 0.013 . Both these values are significant at $10 \%$ significance level. Thus we cannot accept the null hypothesis. In other words, we can conclude that the Income of inland fisherman is positively related to its land, days of fishing, hours of fishing, cost of net used \& water area of production. So the regression co-efficient is significant.

\section{Cost Analysis of Inland Fishery}

Cost of fish production is low in India. The fishermen use net in inland fishery to catch fish. In rainy season, the fishermen purchase fingerlings \& leave in in ponds to grow. So main cost of fishery is expenditure of purchase of fingerlings and cost of net. The cost analysis is done based on primary data collected in the study area. 
Cost is a function of production. So, Cost $=\mathrm{a}+\mathrm{b}$ production

Table-4 Cost function of Inland fisherman

\begin{tabular}{|l|l|l|l|l|}
\hline Cost of net & Coefficient & Standard Error & $\mathrm{t}$ & $\mathrm{P}>|\mathrm{t}|$ \\
\hline Production & 2.261931 & .4733093 & 4.78 & 0.000 \\
\hline Constant & 7787.004 & 559.1839 & 13.93 & 0.000 \\
\hline
\end{tabular}

Cost $=\mathrm{a}+\mathrm{b}$ production--------eq(1)

$$
\mathrm{C}=7787.004+2.261931 \text { production }
$$

$\mathrm{R}^{2}=0.1566, \mathrm{t}=13.93$

Here, p- value is 0.000 . The regression co-efficient is significant. So, Cost \& production are positively co-related as level of fish production increases with increase in cost of production.

\section{Correlation between cost \& Production}

Correlation indicate the linkage and relation between two variables. There is positive correlation between cost and production of fish in study area.The correlation results are given below in table.

\begin{tabular}{|c|c|c|c|}
\hline & & $\operatorname{cost}$ & production \\
\hline \multirow{3}{*}{ Cost } & Pearson Correlation & 1 & $396^{* *}$ \\
\hline & Sig. (2-tailed) & & .000 \\
\hline & $\mathrm{N}$ & 125 & 125 \\
\hline \multirow{3}{*}{ Production } & Pearson Correlation & $396^{* *}$ & 1 \\
\hline & Sig. (2-tailed) & .000 & \\
\hline & $\mathrm{N}$ & 125 & 125 \\
\hline
\end{tabular}

The co-

**. Correlation is significant at the 0.01 level (2-tailed).

relation coefficient between cost \& production 0.396 and the p-value for two tailed test of significance is less than 0.0005.From this figure we can conclude that, there is a strong positive correlation between cost and production and this correlation is significant at the significance level.

\section{Correlation Between Water Area \& Production:-}

Table-6Correlations between water area \& production

\begin{tabular}{|l|l|c|c|}
\hline \multirow{5}{*}{ Water Area } & \multicolumn{1}{|c|}{ Production } \\
\hline \multirow{5}{*}{ Production } & Pearson Correlation & 1 & $.390^{* *}$ \\
\cline { 2 - 4 } & Sig. (2-tailed) & & .000 \\
\cline { 2 - 4 } & $\mathrm{N}$ & 250 & 250 \\
\cline { 2 - 4 } & Pearson Correlation & $.390^{* *}$ & 1 \\
\cline { 2 - 4 } & Sig. (2-tailed) & .000 & 250 \\
\cline { 2 - 4 } & $\mathrm{N}$ & 250 & 2 \\
\hline
\end{tabular}

**. Correlation is significant at the 0.01 level (2-tailed).

The co-relation coefficient between water area \& production 0.390 and the p-value for two tailed test of significance is less than 0.0005. From this figure we can conclude that, there is a strong positive correlation between cost and production and this correlation is significant at the 0.01 level.

Correlation between Land \& production:-

Table-5 Correlations between land production

\begin{tabular}{|c|c|c|c|}
\hline & & Land & Production \\
\hline \multirow{3}{*}{ Land } & Pearson Correlation & 1 & $.323^{* *}$ \\
\hline & Sig. (2-tailed) & & .000 \\
\hline & $\mathrm{N}$ & 250 & 250 \\
\hline \multirow{3}{*}{ Production } & Pearson Correlation & $.323^{* * *}$ & 1 \\
\hline & Sig. (2-tailed) & .000 & \\
\hline & $\mathrm{N}$ & 250 & 250 \\
\hline
\end{tabular}

The co-relation coefficient between Land \& production 0.323 and the p-value for two tailed test of significance is less than 0.0005 . There is a strong positive correlation between Land and production and this correlation is significant at the 0.01 level. 


\section{Conclusion}

The fishery sector is faced internally with overcapacity, underemployment and low per capita earnings and externally by the lack of alternative occupations, low level of literacy and relatively high levels of debt. The challenge is to develop, in this context, a long term policy and a perspective plan allowing for the balanced and sustainable management and development of the fishery sector. Fishery sector has an important role for the development of Odisha economy. Production \& income of fisherman depends upon various independent variables like - land area, age of the fisherman, hours of fishing, days of fishing, cost of net used, water area in acre etc. On an average fishermen is study areas engage in fishing for 7-8 months in a year. The monthly income is widely fluctuating due to seasonal variations in catches and other expenses occurring related to fishing. Monthly income from fishing varying from Rs.4000 - Rs25000. There is urgent need to promote fishery through appropriate policy in Odisha.

\section{References}

[1]. Anjani kumar (2004), Export performance of Indian Fisheries strength challengers Ahead, Economic and Political weekly, September 2004, PP 264-270

[2]. Enalikele, M.D. \& Olutayo A.O.(2010), Explorative Analysis of the effect of inland Fisheries decree on sustanable exploitation of inland fisheries in Lagos State, Nigeria. Journal of Agricultural Extension and Rural Development. Vol.2(8), PP 154-160.

[3]. Fisheries Department Policy Note (2011-2012), Government of Tamilnadu, demand no.7

[4]. Hussain, A.S., 2001, Marketing of inland fish in Lahore district. M.Sc. (Hons.) Thesis. Deptt. Agri. Econ., Uni. Agri., Faisalabad. Hyderabad, India, 11-26 November 1980. Madras, India, September 1981.

[5]. Ibrahim, P.(1992), Fisheries Development in India, Classical publishing Company, New Delhi

[6]. ICLARM, GOI, GoWB, MSSRF, 2003. Fish for all, National Launch, Kolkata, December 18-19, 2003, World Fish Centre (ICLARM), Government of India, Government of West Bengal

[7]. ICLARM, GOI, GoWB, MSSRF, 2003. Fish for all, National Launch, Kolkata, December 18-19, 2003,

[8]. World Fish Centre (ICLARM), Government of India, Government of West Bengal.

[9]. K Ataur Rahman (2003), Understanding livelihoods dependent on inland fisheries in Bangladesh and SE Asia. Fresh Water Fishes in Bangladesh, Dhaka.

[10]. Ngoyen-khao, S. Smith, L.,Lorenzen, K (2005), Impacts of Irrigatiion on Inland Fisheries: Appraisals in Laos and Srilanka, Comprehensive Assessment of Research Report 7. Colombo.

[11]. Pradeep.K, Katiya and Ravi Chandra (1990), The Fish Marketing Efficiency:A case study of Allahabad fish market, Fishing chime, October, pp 1-29.

[12]. Sathiadhas, R. and Narayanakumar, R. 1994. Price policy and fish marketing system in India, Biol. Educ., II (4): 225-241.

[13]. Shyam P. R (2002), C0-management of Common Property Resources: A case study of Supra National, National, Sub-National Institutions in Fisheries Management around Chilika Lake in Odisha, India.

[14]. Srivastava (1999), Aquqculture: Marketing and Economies in India, Aquaculture Research needs for 2000 A.D, Oxford and JIB [] Publishing co., New Delhi, PP 11-325.

[15]. Subha Rao, D.V. and Chodwary, R.K, (1988), A study of marketing factor influencing price of inland fish in selected markets, Indian Journal of Agricultral Marketing . vol.2, pp 170-175. 